\title{
Analysis of platina ores
}

\section{Berzelius Jun.}

To cite this article: Berzelius Jun. (1829) Analysis of platina ores, Philosophical Magazine Series 2, 6:32, 146-146, DOI: 10.1080/14786442908675096

To link to this article: http://dx.doi.org/10.1080/14786442908675096

曲 Published online: 14 Jul 2009.

Submit your article to this journal

LII Article views: 1

Q View related articles $\asymp$ 
luted nitric acid, it possesses this property in common with urea; the acid may be separated from the precipitate by washing with water.-Hensman's Repertoire, January 1829.

ANALYSIS OF PLATINA ORES.-BY BERZELIUS.

Platina ore from Nischne Tagilsk in the Uralian mountains.-This ore is of a dark gray colour, and contains many magnetic grains, some of which possess poles, and the larger are capable of raising small pieces of steel wire. The magnetic and non-magnetic grains were separately analysed, and the results showed that they are essentially and constantly different.
Platina
$2 \cdot 35$
Iridium
4.97
$1 \cdot 15$
Rhodium
0.86
0.30
Iron
0.28
12.98
Copper
$11 \cdot 04$
0.70
Osmiuret of iridium in grains ......... 1.00
$5 \cdot 20$
Insoluble matter $\ldots \ldots \ldots \ldots \ldots \ldots \ldots \frac{2.30}{98.75} \quad \frac{}{97.86}$ in scales
0.96

Non Magnetic. Magnetic.

The insoluble matter of the magnetic grains was a mixture of osmiuret of iridium in grains and scales, with some sand.

Platina ore from Goroblagodat in the Uralian mountains.-This ore is remarkable on account of its being entirely non-magnetic, and because it contains no iridium, except that a trace of it was found in one specimen.

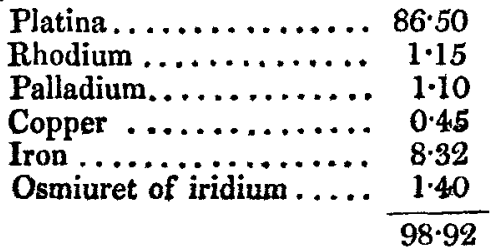

In these three analyses a part of the loss consisted of osmium, which distils during the solution in the acid.

Platina ore from Barbacoas in the province of Antioquła in Colombia.-This ore consists of grains which frequently weigh nearly a gramme ( $15^{*} 4$ grains), mixed with a smaller quantity of smaller grains. The larger grains consisted of

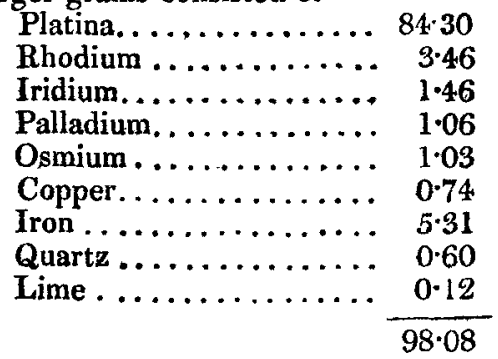

Annales de Chim. et de Phts. April 1829. 
ROSACIC ACID IN HUMAN URINE.

M. Henry, Jun, during an attack of acute rheumatism, accompanied with nervous fever, observed that his urine became of a red colour, and on cooling, that it deposited a very abundant orange precipitate. On examination he found that it contained much rosacic acid, phosphoric acid, and phosphate of lime, but that the uric acid had disappeared and been replaced by the rosacic acid.-Journal de Pharmac. xv. p. 228.

SILICATE OF IRON FROM BODENMAIS.

Professor Kobell of Munich reduced this ore to fine powder, and acted upon it with muriatic acid, and it yielded nearly

$$
\begin{aligned}
& \text { Silica ............. } 31.28 \\
& \text { Peroxide of iron ...... } 50.86 \\
& \text { Water ........... } 19.12 \\
& 101 \cdot 26
\end{aligned}
$$

It is therefore to be considered as an hydrated silicate of iron.Annales de Chim. et de Phys. April 1829.

\section{Calcareous crystals iN THE TISSUES OF LIVING VEgE- \\ TABLES.}

M. Raspail, in a late memoir, shows that the crystals of the pandani, orchides, scilla, \&c., in short, all those which are about $\frac{1}{10}$ th of a millimetre in length, and ${ }_{3}^{1}$ th in breadth, are hexahedral crystals of phosphate of lime; and that the crystals of the tubercles of the iris, which are $\frac{1}{3}$ rd of a millimetre in length, and $y^{1}$ th in breadth, are rectangular crystals of oxalate of lime. It was by means of a magnifying power of from 1000 to 2000 diameters that these new researches were established. These crystals, it will be remembered, were taken for microscopic hairs; and very recently an author imagined he saw them perforated in the middle of their length, and figured them as such.-Jameson's Journal, July 1829.

\section{CHLORIDE AND IODIDE OF AMMONIA.}

M. Serullas has announced to the French Academy, that the substances usually termed chloride and iodide of azote contain hydrogen; or in other words, that they are chloride and iodide of ammonia.-He has promised a memoir on the subject. - Le Globe, April 11th \& 18th.

\section{DECOMPOSITION OF AMMONIA BY METALS.}

M. Despretz, who first announced that metals when subjected to heat and ammoniacal gas, underwent a considerable change of density, has also discovered that the weight of iron is sometimes increased as much as $11 \frac{\mathrm{I}}{2}$ per cent, owing to its combining with azote; but if the heat be too great, then the azote is again expeiled. -Ibid. April 11. 